\title{
18. UPPER BARREMIAN-LOWERMOST APTIAN ORBITOLINID FORAMINIFERS FROM THE GRAND BANKS CONTINENTAL RISE, NORTHWESTERN ATLANTIC (DSDP LEG 43, SITE 384)
}

\author{
Rolf Schroeder, Geologisch-Palaontologisches Institut der Universität Frankfurt a.M., Germany \\ and \\ Antonietta Cherchi, Istituto di Geologia e Paleontologia dell’Universita di Cagliari, Italy
}

\section{INTRODUCTION}

During Leg 43, Lower Cretaceous bioclastic limestones containing orbitolinid foraminifers were recovered at Site 384 in the northwestern Atlantic. This site is situated on the $J$ anomaly ridge, a protrusion at the base of continental rise south of the Grand Banks (see Figure 1). The coordinates of this hole are: latitude $40^{\circ} 21.65^{\prime} \mathrm{N}$, longitude $51^{\circ} 39.80^{\prime} \mathrm{W}$. A detailed lithological description of the bioclastic limestones, which are underlain below 325 meters by weathered basalt (basement), is given in the report for Site 384 (Chapter 4 , this volume).

Orbitolinid foraminifers were found in Core 16, Section 1, Core 20, Section 1, and Core 21, Section 1, in association with pachydont pelecypods and other reefal forms. The few specimens from Core 16 (cored interval 202.2-211.5 m) are rather poorly preserved; they seem to belong to a dictyoconid form with pillars in the interiors of chambers. In Core 21, Section 1, orbitolinid foraminifers are abundant and relatively well preserved (cored interval 324.3-324.8 m). All specimens from this core belong to the two species Palorbitolina lenticularis (Blumenbach, 1805) and Paleodictyoconus arabicus (Henson, 1948), discussed below.

\section{SYSTEMATIC DESCRIPTION}

Family ORBITOLINIDAE Martin, 1889

Genus PALEODICTYOCONUS Moullade, 1965

Paleodictyoconus arabicus (Henson), 1948

(Plate 1, Figures 3-7; Plate 2, Figures 1, 2, 4, 5)

Dictyoconus arabicus Henson, 1948, p. 35, pl. 1, fig. 5-8; pl. 14, fig. $1-12$.

Dictyoconus arabicus Henson, Hofker, Jr., 1966, p. 19, pl. 6, fig. 5, 6.

Paleodictyoconus arabicus (Henson), Schroeder, Conrad, Charollais, 1968, p. 214.

Paleodictyoconus arabicus (Henson), Schroeder, Cherchi, Guellal, Vila, 1974, p. 3, pl. 1, fig. 8, 9; pl. 2, fig. 9, 10.

Remarks: This species, originally described as D. arabicus, was attributed to Paleodictyoconus Moullade for the first time by Schroeder et al., 1968, on the basis of the presence of interseptal pillars merging into rudimentary partitions in the upper part of chambers. The dimensions of specimens from Section 384-21-1 (see Figure 2) and topotypes are similar. The slightly eccentric position of the megalospheric embryo, which consists of two chambers, is clearly visible (Plate 1, Figure 6; Plate 2, Figure 2). Rudimentary partitions are radially arranged within the outer part of the central zone of the chambers (Plate 1, Figure 5) and become labyrinthic in the center of this zone (Plate 2, Figure 1).
Noteworthy is the presence within the septa of numerous agglutinated specimens of Nannoconus sp. This is discussed further below.

Genus PALORBITOLINA Schroeder, 1963

Palorbitolina lenticularis (Blumenbach), 1805

(Plate 1, Figures 1, 2; Plate 2, Figure 3)

Madreporites lenticularis Blumenbach, 1805, pl. 80, fig. 1-6.

Orbitolina lenticularis (Blumenbach), Douglass, 1960, p. 31, pl. 1, fig. 1-26.

Orbitolina (Palorbitolina) lenticularis (Blumenbach), Schroeder, 1963, p. 348 , pl. 23 , fig. 1-9; pl. 24, figs. 1-10 (also for further synonymy).

Palorbitolina lenticularis (Blumenbach), Schroeder, 1964, p. 465.

Remarks: The embryonic apparatus of $P$. lenticularis is distinctly characterized by its large embryonic cavity, which is covered by a layer of small chamberlets and surrounded by the periembryonic ring (Plate 1, Figures 1,2). Among the predominantly calcareous specimens of Section 1 of Core 21 there occur others with coarsely agglutinated tests. The latter seem to be reworked and for this reason the Palorbitolina population is probably not homogeneous.

\section{AGGLUTINATED NANNOCONUS IN THE TESTS OF PALEODICTYOCONUS ARABICUS}

In Section 384-21-1, tiny circular or elliptical structures occur in large quantities within the septa of Paleodictyoconus arabicus, especially visible in horizontal sections (Plate 2, Figures 4, 5). Without doubt these structures represent sections of globular or pear-shaped specimens of Nannoconus sp. which were agglutinated by Paleodictyoconus. These Nannoconus are generally $0.03 \mathrm{~mm}$ in diameter. The wall consists of minute wedges more or less perpendicular to the surface of the test (Plate 1, Figures 8, 9; Plate 2, Figure 5). Their pointed ends are directed toward the internal cavity.

It has long been known that orbitolinids incorporate biogenic fragments (minute foraminifers and sponge spicules) within their test. Schroeder (1965) and Reiss et al. (1966), for example, have independently shown that the curious "calcite eyes" of orbitolinids are in reality agglutinated kidney-shaped sponge spicules. It is also known that smaller foraminifers occasionally incorporate nannofossils into their tests. Luterbacher (1975, pl. 5), for example, has illustrated a specimen of Gaudryina compacta Grabert whose wall consists almost exclusively of neatly arranged Watznaueria sp. This, then, is the first record of the utilization of nannofossils by orbitolinids in the construction of their test.

The tests of Nannoconus have been incorporated principally within the central zone of the septa of 


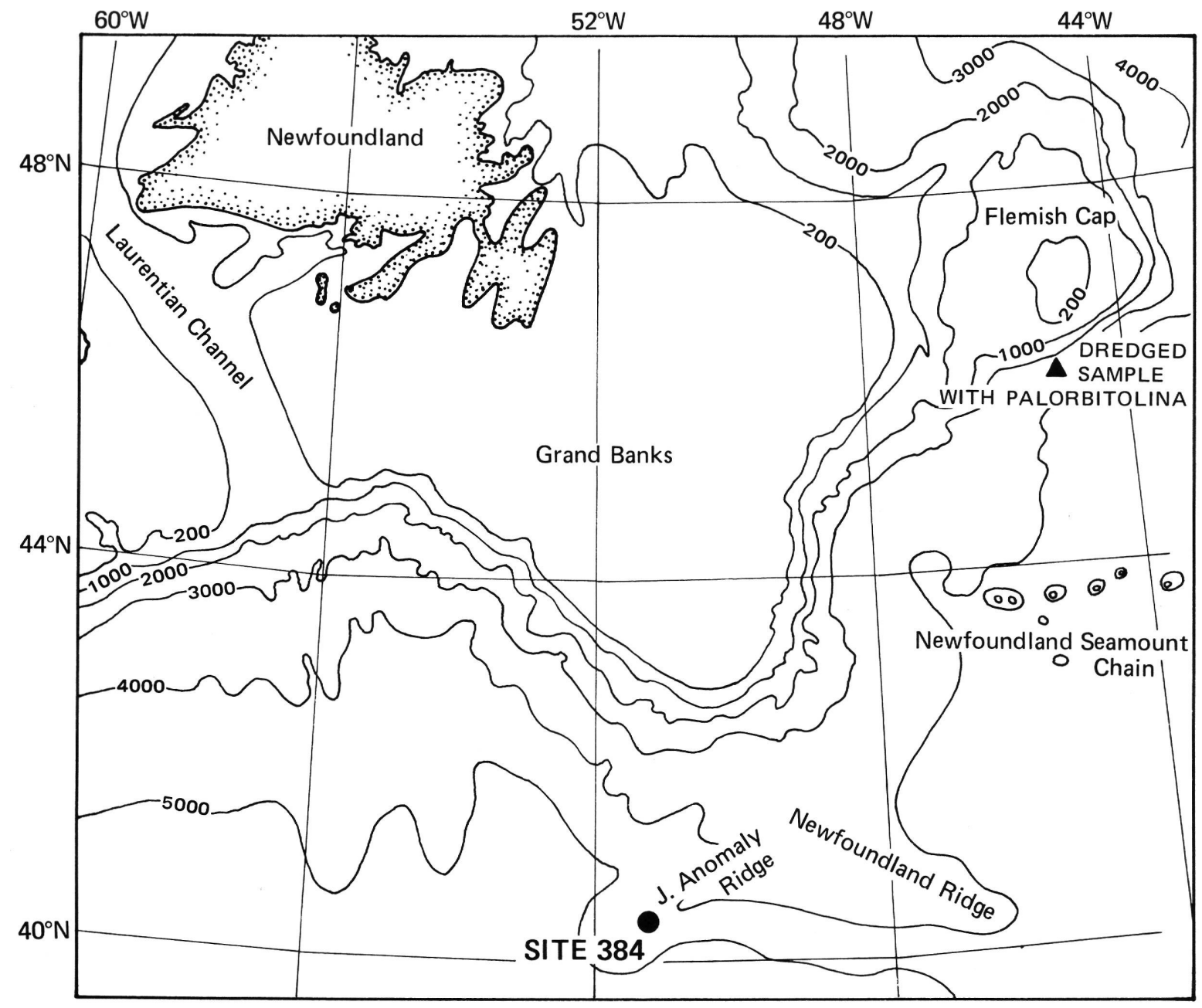

Figure 1. Location of Site 384 (DSDP) and dredged sample (Sen Gupta and Grant, 1971) with Palorbitolina lenticularis south of Flemish Cap.

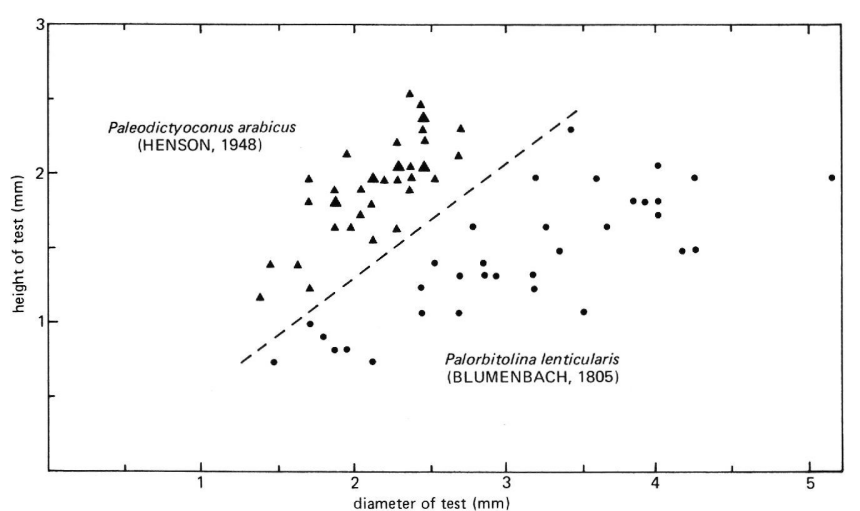

Figure 2. Comparison of dimensions of Paleodictyoconus arabicus (Henson) (triangles) and Palorbitolina lenticularis (Blumenbach) (circles) in Section 384-21-1.

Paleodictyoconus, often forming an inner layer of closely arranged individuals (Plate 1, Figure 9). They are very rare within the interseptal structures and completely lacking in the marginal zone of chambers. Their distribution within the test is therefore compara- ble with the distribution of other agglutinated components in orbitolinid foraminifers.

\section{AGE OF THE FAUNA}

Paleodictyoconus arabicus was described by Henson (1948) from the Barremian (?) of the Qatar peninsula (Arabia), where it occurs together "Orbitolina discoidea Gras var. delicata" Henson (= Palorbitolina lenticularis; cf. Schroeder, 1963) and Choffatella decipiens. The presence of $P$. lenticularis excludes a lower Barremian date.

In Central Iran (in the region of Esfahan) Paleodictyoconus arabicus was reported by Seyed-Emami et al. (1971) from the "Lower Orbitolina limestone" which contains also "Orbitolina lenticularis." This limestone is underlain by yellow dolomites with Matheronites (= Hemihoplites) soulieri (Math.), indicating upper Barremian, and followed by "Orbitolina"'-bearing shales and marls with Prodeshayesites tenuicostatus (Koenen), P. bodei (Koenen), and Deshayesites cf. deshayesi (d'Orbigny), indicating lower Aptian. The "Lower Orbitolina limestone" was therefore regarded by Seyed-Emani et al. (1971) as upper Barremian. 
Paleodictyoconus arabicus also occurs in the lower Barremian of Kopet Dagh (Turkmenistan, USSR), where it was described as Dictyoconus arabicus and D. walnutensis (Carsey) by Mamontova (1961); the species is likewise present in the Iranian part of Kopet Dagh (unpublished).

In the western Mediterranean region, Paleodictyoconus arabicus was recorded by Schroeder et al. (1974) from various localities of the Constantine region (northeastern Algeria). There, the species always occurs with Palorbitolina lenticularis, and in one instance with numerous Barremian cephalopods. It was therefore dated by Schroeder et al. (1974) as uppermost Barremian.

The above data all indicate that Paleodictyoconus arabicus is restricted to the Barremian. In Lebanon, however, this species was reported by Saint-Marc (1970, pl. 1, fig. 12, 13, 15; non fig. 14) from the lower half of the so-called "Falaise de Blanche." This formation contains in its uppermost part Praeorbitolina wienandsi Schroeder (erroneously determined as "Mesorbitolina lotzei" by Saint-Marc), a characteristic species of the upper part of lower Aptian. It is therefore possible that $P$. arabicus ranges into the Aptian. It can further be noted that the "Paleodictyoconus arabicus Zone" from Bicaz Valley (East Carpathians, Romania), established by Dragastan (1975), was dated by him as lower Aptian, which he based on the date published by Saint-Marc (1970) from Lebanon. No other paleontological indications for the lower Aptian age are given. On the basis of the available data therefore, the stratigraphic range of Paleodictyoconus arabicus, is Barremian to lowermost Aptian, with its maximum development in the upper Barremian.

Palorbitolina lenticularis (Blumenbach), as revised by Schroeder (1963), is a geographically widespread species of the Old World Tethys, and it is impossible to enumerate all the known localities. According to Schroeder (1963), this species ranges from the upper Barremian to the base of the upper Aptian. In the New World "Orbitolina lenticularis" has been reported from Venezuela (Dietrich, 1924), Colombia (Karsten, 1858), and Texas (Douvillé, 1900). It is difficult, however, to determine whether these forms are conspecific with Palorbitolina lenticularis as no structural details are given. True Palorbitolina lenticularis was described by Sen Gupta and Grant (1971) from the Flemish Cap (western North Atlantic, see Figure 1) under the name Orbitolina conoidea Gras $(=P$. lenticularis; see Schroeder, 1963). An exact age is not given, and the reported range (of "O. conoidea") given by Sen Gupta and Grant (1971) ("Neocomian to Cenomanian, with the maximum development in Aptian") has been obsolete for a long time. The Flemish Cap Palorbitolinas that are not associated with Paleodictyoconus arabicus are upper Barremian to basal upper Aptian.

The conjunction of the stratigraphical ranges of Paleodictyoconus arabicus (Barremian-lowermost Aptian) and Palorbitolina lenticularis (upper Barremianbase of upper Aptian) suggests that the orbitolinid fauna of Section 384-21-1 is upper Barremian-lowermost Aptian.

At present, this association, together with the Flemish Cap Palorbitolinas, can be considered the oldest orbitolinid fauna of the New World.

\section{PALEOBIOGEOGRAPHICAL POSITION OF THE FAUNA}

On the basis of orbitolinid foraminifers, Cherchi and Schroeder (in Schroeder et al., 1974) could differentiate two biogeographic provinces in the neritic Barremian of the western Mediterranean region. The northern province (Eastern Pyrenees, southeastern France, Sardinia) is characterized by the so-called "Valserinaassociation"'(Cherchi and Schroeder, 1973). The characteristic species of the southern province (southern part of Italian peninsula, with Sicily and northern Algeria) are Paleodictyoconus arabicus and Orbitolinopsis capuensis (De Castro).

Because of the presence of $P$. arabicus the orbitolinid fauna of Site 384 belongs to the southern province. Taking into consideration the paleogeographic position of the western Mediterranean region and northern America during the Early Cretaceous (Dietz and Holden, 1970), this fauna represents the most westerly known extension of this province.

\section{ACKNOWLEDGMENTS}

We wish to thank the Scientific Party of Deep Sea Drilling Project Leg 43, particularly P. Rothe for placing at our disposal this interesting material. Thanks are also due to E. Martini for confirmation of our observations regarding the existence of Nannoconus sp. within the septa of Paleodictyoconus arabicus.

\section{REFERENCES}

Cherchi, A. and Schroeder, R., 1973. Sur la biogéographie de l'association à Valserina du Barrémien et la rotation de la Sardaigne: C. R. Acad. Sci. Paris, v. 277, p. 829-832.

Dietrich, W. O., 1924. Zur Palaontologie und Stratigraphie der Kreide und des Tertiars in der ostkaribischen Kordillere Venezuelas: Centralbl. Mineral., p. 181-187.

Dietz, R. S. and Holden, J. C., 1970. Reconstruction of Pangaea: breakup and dispersion of continents, Permian to present: J. Geophys. Res., v. 75, p. 4939-4956.

Douvillé, H., 1900. Sur quelques Rudistes americains (Mexique et Texas): Soc. Géol. France Bull., v. 28, p. 205221.

Dragastan, O., 1975. Upper Jurassic and Lower Cretaceous microfacies from Bicaz valley basin (East Carpathians): Mém. Inst. Géol. Géophys. Bucarest, v. 21, p. 1-88.

Henson, F. R. S., 1948. Larger imperforate foraminifera of South-Western Asia. Families Lituolidae, Orbitolinidae and Meandropsinidae: British Mus. (Nat. Hist.), p. 1-127.

Karsten, H., 1858. Uber die geognostischen Verhältnisse des westlichen Columbien, der heutigen Republik Neu-Granada und Equador: Amtl. Ber. 32. Versamml. deutsch. Naturf. Arzte Wien, p 80-117.

Luterbacher, H., 1975. Early Cretaceous foraminifera from the northwestern Pacific: Leg 32 of the deep Sea Drilling Project. In Larson, R. L., Moberly, R., et al. Initial Reports of the Deep Sea Drilling Project, v. 32: Washington (U.S. Government Printing Office), p. 703-718. 
Mamontova, E., 1961. Orbitolinidy. In Neokom Sapadnoj Turkmenii: Problema Neftegazonostosi srednej Azii, v. 51, p. 72-92.

Montanari, L., 1964. Geologia del Monte Pellegrino (Palermo): Riv. mineraria siciliana, no. 88-90, p. 1-64.

Reiss, Z., Derin, E., and Gerry, E., 1966. O tak nazyvaemych "kalcitorych glaznach" v stenke rakovin aggljutinirujuščich foraminifer: Voprosy Mikropaleontol., v. 10 (Akad. Nauk SSSR), p. 234-242.

Saint-Marc, P., 1970. Contribution a la connaissance du Crétacé basal au Liban: Rev. Micropaléontol., v. 12, p. 224-233.

Schroeder, R., 1963. Palorbitolina, ein neues Subgenus der Gattung Orbitolina (Foram.): N. Jb. Geol. Paläont. Abh., v. 117 (Festband Lotze), p. 346-359.
1965. Die "Kalzit-Augen" der Orbitolinen und ihre Deutung: N. Jb. Geol. Paläont. Mh., p. 135-140.

Schroeder, R., Cherchi, A., Guellal, S., and Vila, J.-M., 1974. Biozonation par les grands Foraminifères du Jurassique supérieur et du Crétacé inférieur et moyen des séries néritiques en Algérie NE. Considérations paléobiogéographiques: Sixth Coll. Africain Micropaléontol., Tunis (1974), preprint (Cagliari, Italy), p. 1-8.

Sen Gupta, B. K. and Grant, A. C., 1971. Orbitolina, a Cretaceous larger foraminifer, from Flemish Cap: paleoceanographic implications: Science, v. 173, p. 934-936.

Seyed-Emami, A., Brants, A., and Bozorgnia, F., 1971. Stratigraphy of the cretaceous rocks southeast of Esfahan: Geol. Surv. Iran Rept., no. 20, p. 5-27. 


\section{.}




\section{PLATE 1}

All specimens from Section 384-21-1, upper Barremian.

Figures 1, 2 Palorbitolina lenticularis (Blumenbach), 1805.

Axial sections through two young specimens showing megalospheric embryo. $48 \times$.

Figures 3-7 Paleodictyoconus arabicus (Henson), 1948.

3-5. Horizontal sections showing apertures, and interseptal pillars merging into rudimentary partitions. $30 \times$.

6. Axial section through a young specimen showing the eccentrically situated bichambered embryo. $48 \times$.

7. Axial section through an adult specimen. The embryonic part is destroyed. $48 \times$.

Figures 8, 9 Nannoconus sp. agglutinated in Paleodictyoconus arabicus.

8. Longitudinal section through a pear-shaped specimen of Nannoconus sp. agglutinated within an interseptal partition of Paleodictyoconus arabicus. $520 \times$.

9. Horizontal section through a part of a septum of Paleodictyoconus arabicus consisting almost exclusively of closely arranged Nannoconus sp. $520 \times$. 
PLATE 1
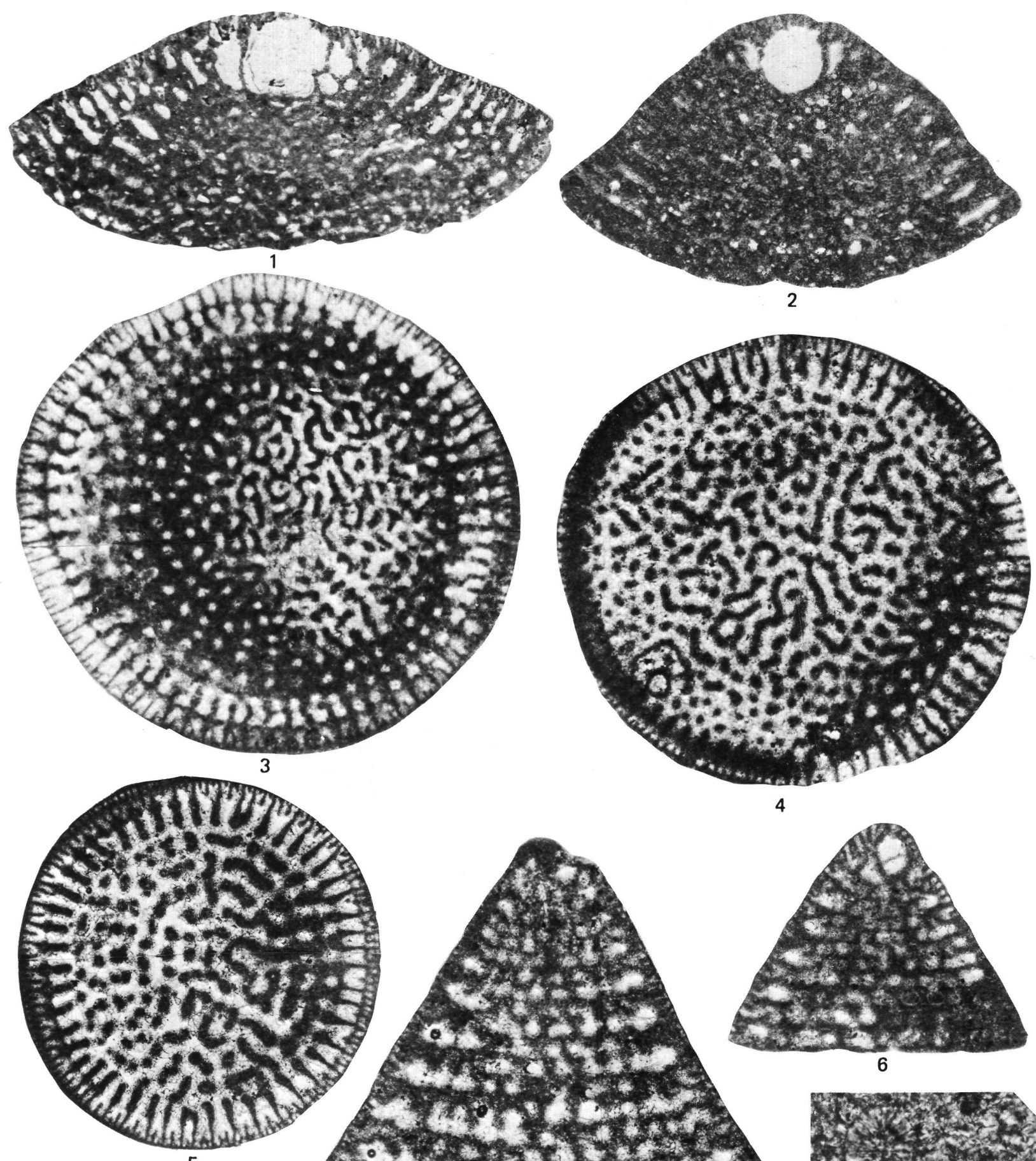

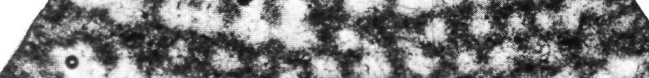

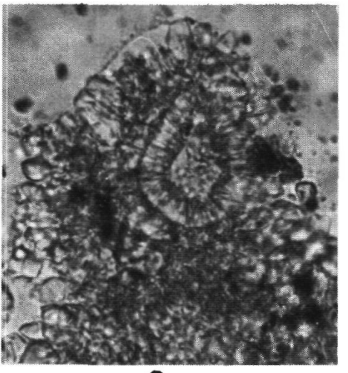

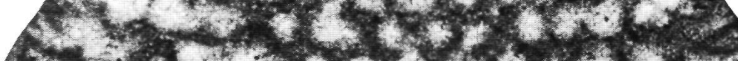

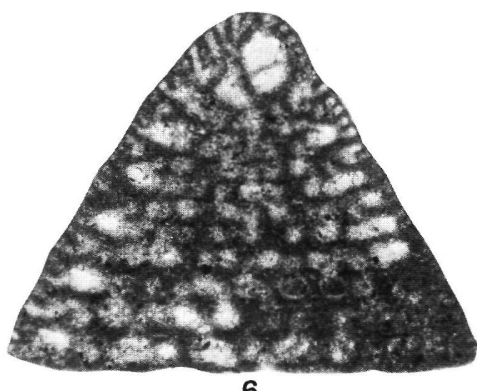

6

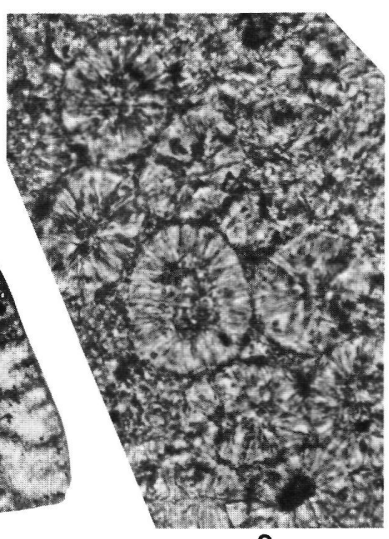

9 


\section{PLATE 2}

All specimens from Section 384-21-1, upper Barremian.

Figures 1, 2 Paleodictyoconus arabicus (Henson), 1948.

1. Horizontal section showing apertures, and interseptal pillars merging into rudimentary partitions. $30 \times$.

2. Axial section showing the eccentrically situated bichambered embryo. $48 \times$.

Figure 3 Palorbitolina lenticularis (Blumenbach), 1805. Axial section passing within the embryonic apparatus through the chamberlets of the periembryonic ring. $30 \times$.

Figures 4, 5 Paleodictyoconus arabicus (Henson), 1948. Particular of Figure 1 showing agglutinated Nannoconus (tiny white rings) within the dark septum.

4. $48 \times$.

5. $130 \times$. 
PLATE 2
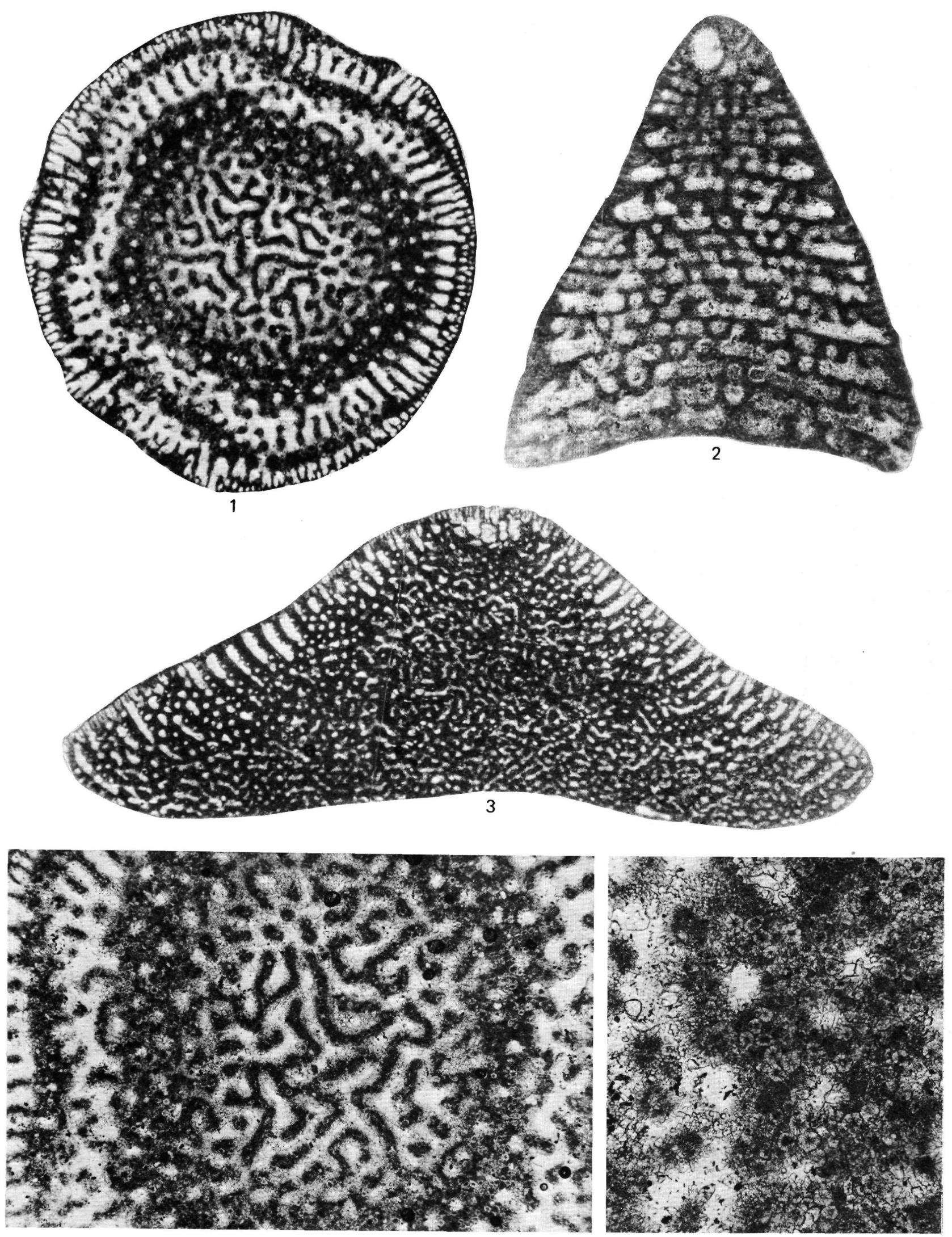